\title{
Cranial vault reconstruction with bone morphogenetic protein, calcium phosphate, acellular dermal matrix, and calcium alginate in mice ${ }^{1}$
}

\author{
Ciro Paz PortinhoI, Luís Alberto Santos ${ }^{\mathrm{II}}$, Thadeu Cerski ${ }^{\mathrm{III}}$, Raquel Camara Rivero ${ }^{\mathrm{IV}}$, Marcus Vinícius Martins Collares ${ }^{\mathrm{V}}$ \\ DOI: http://dx.doi.org/10.1590/S0102-8650201400160001 \\ IFellow PhD degree, Postgraduate Program in Surgical Sciences, Medical School, Federal University of Rio Grande do Sul (UFRGS), Brazil. Master, \\ Attending Physician, Plastic Surgery Department, Porto Alegre Clinics Hospital (HCPA), Brazil. Concept and design of the study, acquisition and \\ interpretation of data, manuscript writing, English language, supervised all phases of the study. \\ IIPhD, Associate Professor, Head, Laboratory of Biomaterials and Advanced Ceramics (LABIOMAT), Material Engineering Department, UFRGS, \\ Brazil. Scientific and intellectual content of the study, scaffold design, critical revision. \\ IIIPhD, Assistant Professor, Head Pathology Department, HCPA/UFRGS, Brazil. Histopathological examinations, critical revision. \\ ${ }^{\mathrm{IV}}$ Master, Associate Professor, Pathology Department, HCPA/UFRGS, Brazil. Histopathological examinations, critical revision. \\ ${ }^{v} \mathrm{PhD}$, Assistant Professor, Head Plastic Surgery Department, HCPA/UFRGS, Brazil. Scientific and intellectual content of the study, critical revision.
}

\section{ABSTRACT}

PURPOSE: To evaluate experimental cranial vault reconstructions, by combining bone morphogenetic protein type 2 (BMP-2) and different matrices.

METHODS: Fourty-nine animals were initially included (seven per group). We designed an experimental, open, prospective and comparative study, divided in seven groups: 1 - BMP-2+calcium phosphate (BT); 2 - BMP-2+acellular dermal matrix (BM); 3 - BMP$2+$ calcium alginate (BA); 4 - TCP; 5 - MDM; 6-ALG; 7 - Bone autograft (BAG). A bone failure was created in left parietal bone of adult male mice. At the same procedure reconstruction was performed. After five weeks, animals were sacrificed, and reconstruction area was removed to histological analysis. After exclusion due to death or infection, thirty-eight animals were evaluated $(\mathrm{BT}=5$; $\mathrm{BM}=6$; $\mathrm{BA}=6 ; \mathrm{TCP}=7 ; \mathrm{MDM}=3 ; \mathrm{ALG}=6 ; \mathrm{BAG}=5)$.

RESULTS: A higher incidence of infection has occurred in MDM group (57\%, P=0.037). In cortical fusion, groups BAG, TCP, and BMP-2+TCP (BT) obtained the best scores, comparing to the others $(\mathrm{P}=0.00846)$. In new bone formation, groups $\mathrm{BT}$, $\mathrm{BAG}$, and TCP have presented the best scores $(\mathrm{P}=0.00835)$. When neovascularization was considered, best groups were $\mathrm{BMP}-2+\mathrm{MDM}(\mathrm{BM}), \mathrm{BMP}-$ $2+\mathrm{ALG}(\mathrm{BA}), \mathrm{TCP}$, and MDM $(\mathrm{P}=0.001695)$. BAG group was the best in bone marrow formation, followed by groups $\mathrm{BT}$ and TCP $(\mathrm{P}=0.008317)$.

CONCLUSIONS: Bone morphogenetic protein type 2 increased bone regeneration in experimental skull reconstruction, especially when combined to calcium phosphate. Such association was even comparable to bone autograft, the gold-standard treatment, in some histological criteria.

Key words: Bone and Bones. Bone Transplantation. Tissue Engineering. Bone Matrix. Craniofacial Abnormalities. Mice. 


\section{Introduction}

Craniofacial reconstructions often need either bone or cartilage autografts ${ }^{1}$. Cranial reconstruction is important not only for cosmetic concerns, but also to re-establish protection to brain and prevent central blood flow imbalance due to atmospheric pressure ${ }^{2}$. Bone tissue is able to regenerate after damage ${ }^{3}$. Under ideal conditions, bone architecture is rebuilt, instead of a fibrous scar, which is the common final route of other tissues ${ }^{4}$. However, bone restitution may be challenging, especially when donor areas become scarce or healing is inefficient $^{5-9}$. From this, alternatives have been researched so long ${ }^{10-12}$.

Bone autografts (BAG) keep on going as the gold standard grafts, but they carry some bias: their harvesting produce a variable degree of morbidity in donor area; they are not promptly available in many cases; they may be difficult to sculpt and fit for a certain receptor area ${ }^{1,4,13}$. The advent of both heterologous and synthetic grafts has increased the offer of material, but has also brought other problems, as follows: lack of osteoinduction, resorption unpredictability, and unfavourable mechanical properties ${ }^{1,14-19}$.

There are many ongoing researches, which intend to decrease or even prescind donor areas ${ }^{20,21}$. Tissue engineering (TE) has looked for the combined use of regenerative cells, matrices or cell carriers, and growth factors $(\mathrm{GF})^{1,22-33}$. There are some controversial evidences showing lack in cranial vault reconstructions when ADSCs are used ${ }^{34,35}$. Yet, studies with bone morphogenetic protein (BMP) and no cell addiction have demonstrated the great osteoconductive and osteoinductive capacity of this growth factor. These findings challenge the concept of cell culture inclusion ${ }^{19}$. This way, it has become important to evaluate the effects of combining GF (e.g., BMP) and matrices, without adding regenerative cells.

GF interact with cell metabolism. In bone tissue, cell proliferate significantly in vitro in response to the following growth factors: BMP - especially type 2 and 7; fibroblast growth factor-2 (FGF-2); platelet-derived growth factor (PDGF); insulin-like growth factor-1 (IFG-1); and vascular endothelial growth factor (VEGF) $)^{1,4}$. Among them, BMP have been considered the greatest mediators either in osteogenesis and bone regeneration ${ }^{18}$. BMP belong to transforming growth factor-beta (TGF-beta) family, and they have been intensively studied $^{18,19,36-38}$. BMP are believed to start and accelerate a fracture healing, and also to decrease the risk of bone nonunion ${ }^{39}$.

The aim of this paper was to evaluate, through a histological scale, bone regeneration of a parietal cranial vault reconstruction in mice, which have been submitted to reconstructions with BMP-2, associated to TCP, MDM, or ALG.

\section{Methods}

This project has been approved by Bioethics Committee from Porto Alegre Clinics Hospital, and registered as \# 12-0199.

We have designed an experimental, comparative and prospective study. We have used isogenic Balb-C57 mice. They were all adults and males. They were included following the criteria of Animal Experimental Research Department (AERD) - Porto Alegre Clinics Hospital - Federal University of Rio Grande do Sul. During experiences, the animals have been kept in adequate places, under a 12-hour cycle of light/darkness, receiving proper food and potable water ad libitum. Animal care has followed the Law 11,794, which determines protocols for animal research. Surgeries and lodgement were made at AERD.

We have divided the mice population into seven groups:

$$
\begin{aligned}
& \text { - } \mathrm{G} 1=\mathrm{BMP}+\mathrm{TCP}=\mathrm{BT} \\
& \text { - } \mathrm{G} 2=\mathrm{BMP}+\mathrm{MDM}=\mathrm{BM} \\
& \text { - } \mathrm{G} 3=\mathrm{BMP}+\mathrm{ALG}=\mathrm{BA} \\
& \text { - } \mathrm{G} 4=\mathrm{ALG}[\text { control }] \\
& \text { - } \mathrm{G} 5=\mathrm{MDM}[\text { control }] \\
& \text { - } \mathrm{G} 6=\mathrm{TCP}[\text { control] } \\
& \text { - } \mathrm{G} 7=\mathrm{BAG} \text { [control; gold standard }]
\end{aligned}
$$

We have determined the number of animals to be included based on previous published articles, in which cranioplasties and craniofacial bone reconstructions have been made. Arias-Gallo et $a l .{ }^{4}$ included 48 animals, divided by six groups (eight animals per group). Özdemir et al ${ }^{40}$ included 28 animals, divided by six groups (four animals per group). Lópiz-Morales et al. ${ }^{36}$ included 26 animals (52 bone failures; nine groups). Moshaverinia et al. ${ }^{18}$ included 20 animals, divided by five groups (four animals per group). Poldervaart et al. ${ }^{19}$ included 16 animals, unequally divided by three groups. Besides, international rules for experimental studies suggest a reduced number of animals per research. This way, we have decided to use 49 animals, divided by seven groups, what means seven animals per group. This would respect such rules, and even a lost of two animals per group would not compromise statistics.

\section{Matrices and cell carriers}

In order to obtain a consistent comparison, we have included a bone matrix (TCP), a dermal matrix (MDM), a cell carrier (ALG), and the gold-standard graft (BAG). Both ALG and TCP were manufactured by Laboratory of Biomaterials and Advanced Ceramics (LABIOMAT), Material Engineering Department, UFRGS, Brazil. MDM chosen was Matriderm ${ }^{\circledR}$ (Endosul distribution, manufactured by Skin \& Health Co., Billerbeck, Germany). BAG was that simply made during the cranial failure creation. It has been totally separated from cranial vault and soon sent back to the failure area. 


\section{Bone morphogenetic protein}

Human recombinant bone morphogenetic protein-2 (BMP-2) has been used in groups BA, BM, and BT (25 $\mu$ g, Interprise Distributor, Immuno ${ }^{\circledR}$, MP Biomedicals, Solon, Ohio, USA). Commercial presentation has been diluted into $2.5 \mathrm{~mL} 0.9 \% \mathrm{NaCl}$, obtaining a concentration at $10 \mu \mathrm{g} / \mathrm{mL}$. Minimal concentration recommended by the manufacturer was $1 \mu \mathrm{g} / \mathrm{mL}$. A volume of 10 $\mathrm{UI}(0.1 \mathrm{~mL})$ was applied in every animal bone failure.

\section{Surgical procedure}

Animals have undergone surgery, according to AERD protocol. Surgical model was the same as previously performed in other studies from our research group ${ }^{16}$. Anaesthesia has been made with isoflurane. Induction has been made with $100 \mathrm{ml} / \mathrm{min}$, and maintained with $30 \mathrm{ml} / \mathrm{min}$. Scalp incision has been arciforme, over left parietal bone, opposed to bone failure region (left parietal bone), in order to prevent straight communication between the study site and environment (Figure 1). Scalp flap has been displaced, and periosteum has been detached, till left parietal bone has been totally exposed.

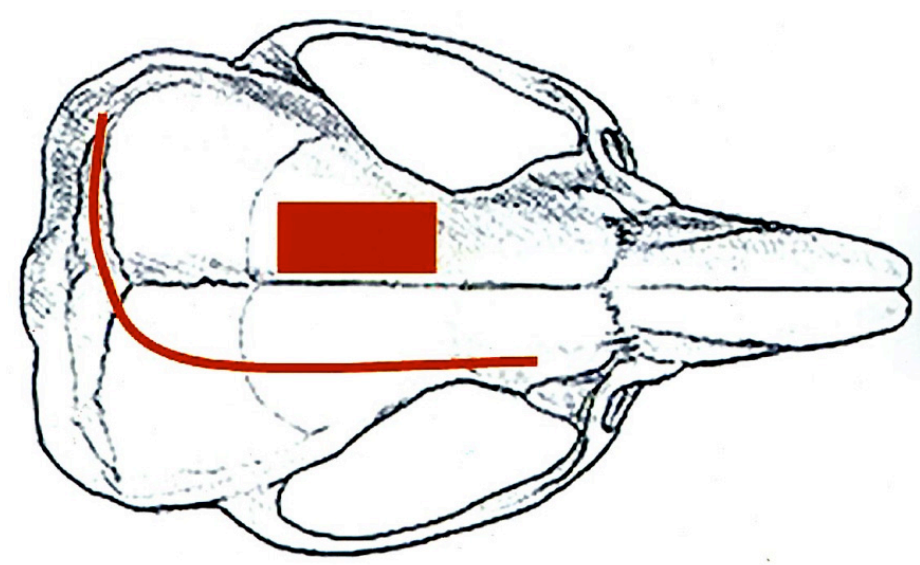

FIGURE 1 - Scalp incision (arcuate line) and left parietal bone region of failure creation (retangle).

A cranial failure, sizing 4 × $5 \mathrm{~mm}$, has been created in left parietal bone, with a drill. This failure has already been studied in previous publications, presenting no spontaneous regeneration ${ }^{16}$. Periosteum has been detached delicately with a Freer detacher. Dura has been preserved as possible. Mice have been reconstructed with some of the combinations previously described (Figure 2). For TCP reconstruction a transoperative preparation was made, combining $1 \mathrm{cc}$ of cement to $1 \mathrm{cc}$ of $0.9 \%$ saline solution. Thereafter, scalp flap has been sutured with nylon 4-0.

Postoperative recovery has been made in appropriate room, in neonatal warmed cradles (temperature between 25 and 30 degrees Celsius). Analgesia has been made with tramadol, $10 \mathrm{mg} /$ $\mathrm{kg}$, subcutaneous or intramuscular each 6 hours. We did not use antibiotics, in order to determinate the capacity of reconstructions to resist against either contamination or infection.

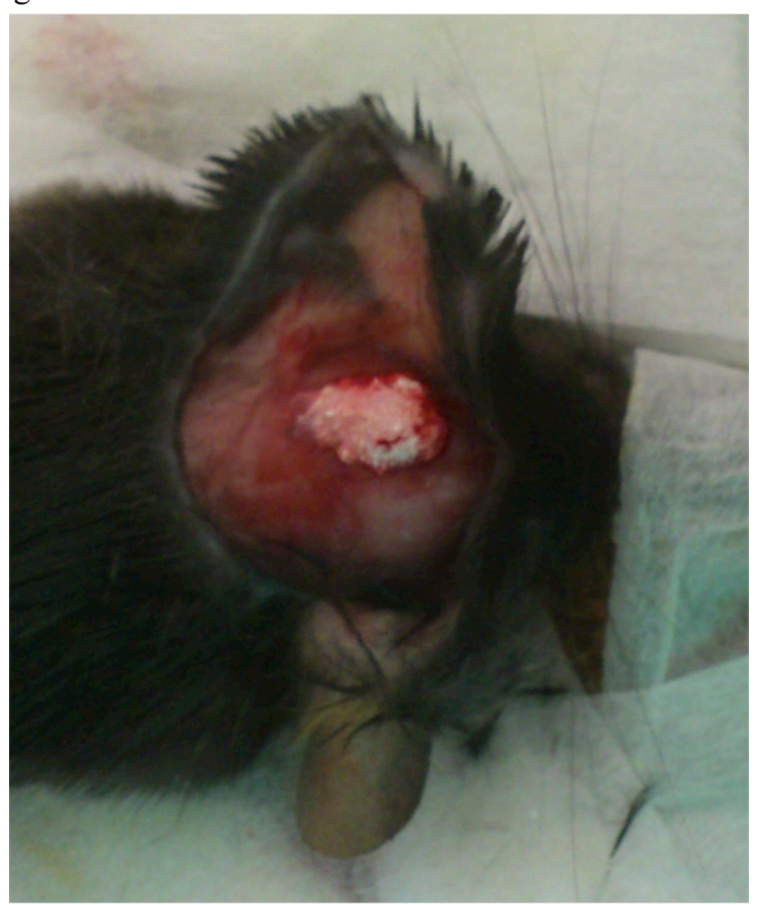

FIGURE 2 - Surgical procedure. Bone failure reconstruction with TCP.

Five weeks after surgery, euthanasia has been made with an overdose of both xylazine and tramadol, according to our institution protocol. Incision was reopen, and the failure content was removed en bloc and kept in formalin for histological preparing.

The five-week period has been chosen because it is intermediate between other studies periods (four or six weeks). We have preferred such design, once we have not projected the analysis of late groups.

\section{Histology and image digitalization}

Surgical samples taken from cranial vaults have been put away in formalin for about one week. After, there has been histological preparation. Staining was made with hematoxylin-eosin (HE).

Imaging digitalization has been made with QCapture Pro $^{\circledR}$ (QImaging Pro Corporation, 2003), version 5.1.1.14 for Windows 2000/XP Professional.

\section{Outcomes determination}

The outcomes have been evaluated by a previously validated histological scale ${ }^{16}$. It consisted on criteria presented in Table 1. Possible sum could range from -3 to 15 points. 
TABLE 1 - Histological criteria for bone regeneration.

\begin{tabular}{|c|c|c|}
\hline CRITERIA & DETAILS & SCORING \\
\hline NEW BONE FORMATION & $\begin{array}{l}\text { Absent: } \\
\text { Until } 1 / 3 \text { of microscopic field: } \\
\text { Until } 2 / 3 \text { of microscopic field: } \\
\text { More than } 2 / 3 \text { of microscopic field: }\end{array}$ & $\begin{array}{l}0 \\
1 \\
2 \\
3\end{array}$ \\
\hline $\begin{array}{l}\text { OLD AND UNABSORBED } \\
\text { MATRIX }\end{array}$ & $\begin{array}{l}\text { Absent: } \\
\text { Until } 1 / 3 \text { of microscopic field: } \\
\text { Until } 2 / 3 \text { of microscopic field: } \\
\text { More than } 2 / 3 \text { of microscopic field: }\end{array}$ & $\begin{array}{l}0 \\
-1 \\
-2 \\
-3\end{array}$ \\
\hline PRESENCE OF CELLS & $\begin{array}{l}\text { Absent: } \\
\text { Until } 1 / 3 \text { of microscopic field: } \\
\text { Until } 2 / 3 \text { of microscopic field: } \\
\text { More than } 2 / 3 \text { of microscopic field: }\end{array}$ & $\begin{array}{l}0 \\
1 \\
2 \\
3\end{array}$ \\
\hline OSTEOCLASTS & $\begin{array}{l}\text { Absent: } \\
\text { Until } 1 / 3 \text { of microscopic field: } \\
\text { Until } 2 / 3 \text { of microscopic field: } \\
\text { More than } 2 / 3 \text { of microscopic field: }\end{array}$ & $\begin{array}{l}0 \\
1 \\
2 \\
3\end{array}$ \\
\hline NEOVASCULARIZATION & $\begin{array}{l}\text { Absent: } \\
\text { Until } 1 / 3 \text { of microscopic field: } \\
\text { Until } 2 / 3 \text { of microscopic field: } \\
\text { More than } 2 / 3 \text { of microscopic field: }\end{array}$ & $\begin{array}{l}0 \\
1 \\
2 \\
3\end{array}$ \\
\hline BONE MARROW & $\begin{array}{l}\text { Absent: } \\
\text { Present: }\end{array}$ & $\begin{array}{l}0 \\
1\end{array}$ \\
\hline CORTICAL FUSION & $\begin{array}{l}\text { Absent: } \\
\text { Present in one side: } \\
\text { Present in both sides: }\end{array}$ & $\begin{array}{l}0 \\
1 \\
2\end{array}$ \\
\hline
\end{tabular}

Evaluation of these criteria has been made in 200 and 400 times optical microscope amplification. Analysis has been made by two pathologists. Blinding could not be complete, once histological images showed a clear difference between reconstruction with bone matrices and others without it. However, blinding could be sustained between the presence of BMP-2 or not.

The criterion "old matrix presence" (not resorbed) has received a negative punctuation, once it represented the absence of deficiency of metabolic activity.

The criterion "cortical fusion" represented the emergence of a new-bone formed bridge between native skull bone and reconstruction area. As the histological evaluation was made so that two native margins could be visualized, it has been possible to determine, in a two-dimensional way, if there has happened no fusion, or fusion in one or both sides.

\section{Statistical analysis}

Statistical analysis has been made by Kruskal-Wallis test for evaluate differences between groups, with significance level for $\mathrm{p}<0.05$.

\section{Biosecurity protocols}

In this project, we have followed Safety Standards and Procedures for Good Laboratory Practice. The necessary security measures were ensured to researchers, either for animal manipulation or stand research.

\section{Ethical aspects}

In vivo procedures has been performed according to present Brazilian legislation (Law \#11,794 - Oct. $8^{\text {th }}, 2008$ ), which has established Procedures for the Scientific Use of Animals and regulates the register of vivariums and research centers. All the procedures are based on Guide for the Care and Use for Laboratory Animals - ILAR/ USA (2011), and on Manual for Vivarium Technicians (COBEA/ Brazil, 1996), projected to diminish pain and discomfort.

\section{Results}

All the animals presented cell colonization in bone failure. Also, all of them had reconstruction material available in receptor area. There has been no scar retraction in any failure. 
Macroscopic calcification of parietal failure has been perceived in groups BAG, TCP, BT, and BM. This measure has not been submitted to statistics because histology would do it with much more precision.

There have been 11 losses through all groups. Incidence of infection has been notorious in MDM group. There have been $4 / 7$ cases $(57 \%)$ in MDM group, $1 / 6$ in BAG group (17\%), and $1 / 7(14 \%)$ in BA group. This analysis was statistically significant $(\mathrm{p}=0.037)$. Evaluations and calculations hereafter refer to remaining animals, after excluding cases of obit and infection.

All the groups have received histological evaluation (Figures 3 to 11). Table 2 presents all the results by group and by animal in detail.

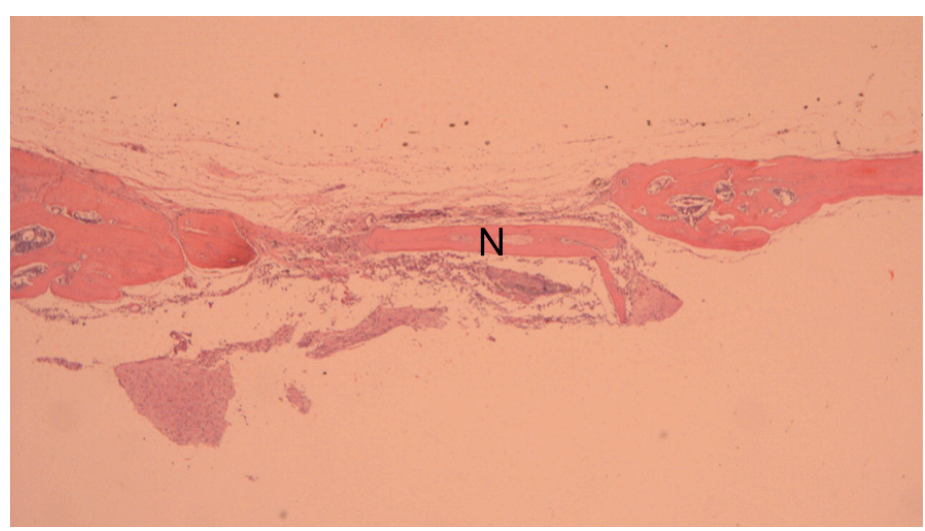

FIGURE 3 - Histological aspect of reconstruction with bone autogenous graft. There is new bone formation $(\mathbf{N})$ in reconstructed area (x50).

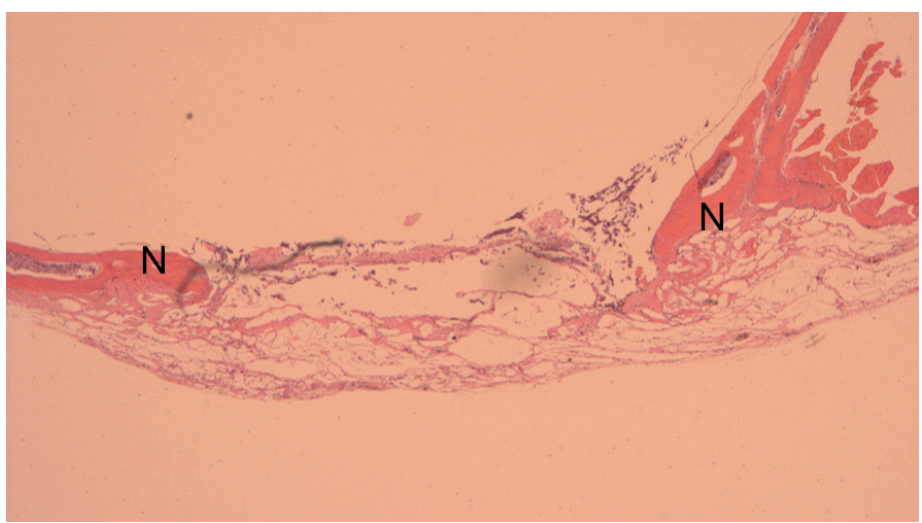

FIGURE 4 - Histological aspect of reconstruction with alginate. There is new bone formation $(\mathbf{N})$ in the border of the failure, where native cranial vault bone can be seen (x50).

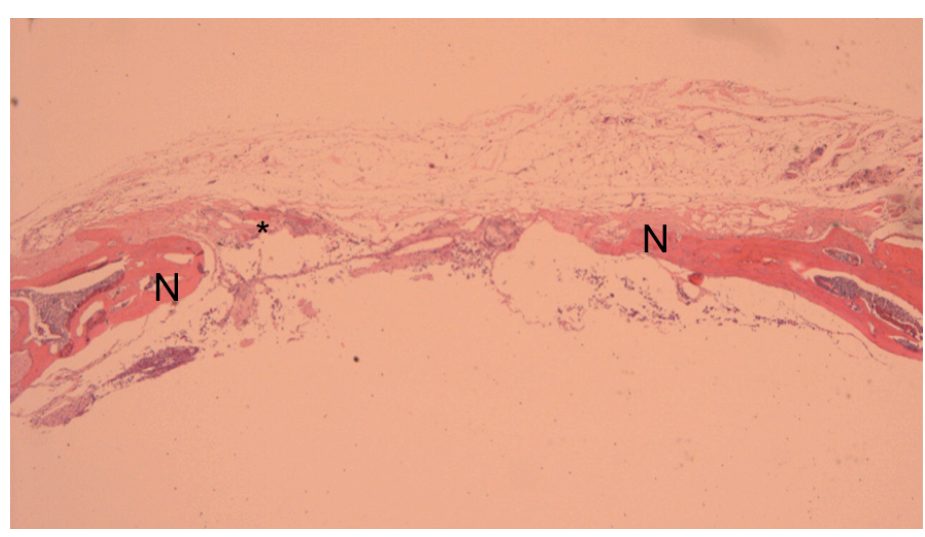

FIGURE 5 - Histological aspect of reconstruction with alginate. This time, there is new bone formation $(\mathbf{N})$ in the border of the failure and also in the middle of reconstructed area $(*)(\mathrm{x} 50)$.

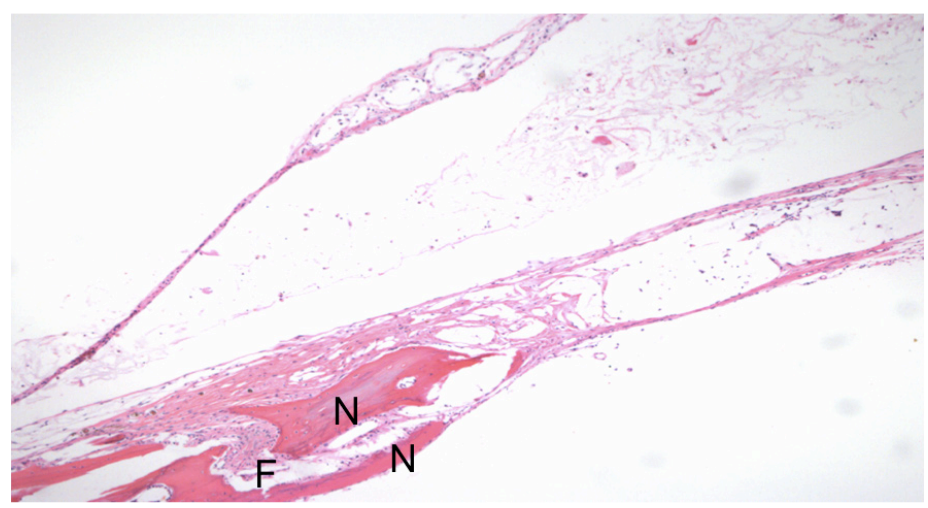

FIGURE 6 - Histological aspect of reconstruction with alginate and bone morphogenetic protein-2. There is new bone formation $(\mathbf{N})$, and cortical fusion (F) (x100).

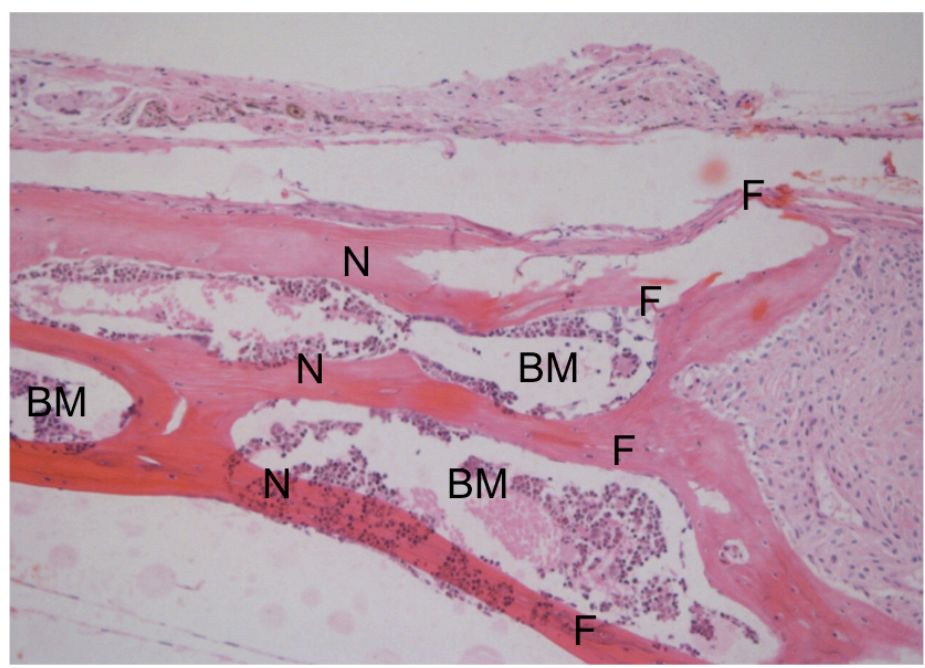

FIGURE 7 - Histological aspect of reconstruction with dermal matrix and bone morphogenetic protein-2. There is new bone formation $(\mathbf{N})$, cortical fusion $(\mathbf{F})$ and the presence of bone marrow $(\mathbf{B M})$ in the reconstructed area $(\mathrm{x} 200)$. 


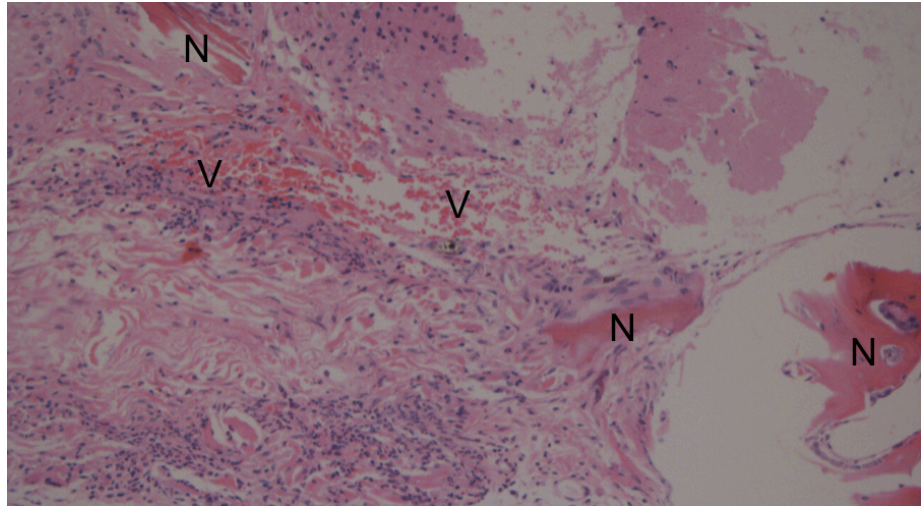

FIGURE 8 - Histological aspect of reconstruction with dermal matrix and bone morphogenetic protein-2. There is new bone formation $(\mathbf{N})$ in some areas and intense neovascularization (V) (x400).

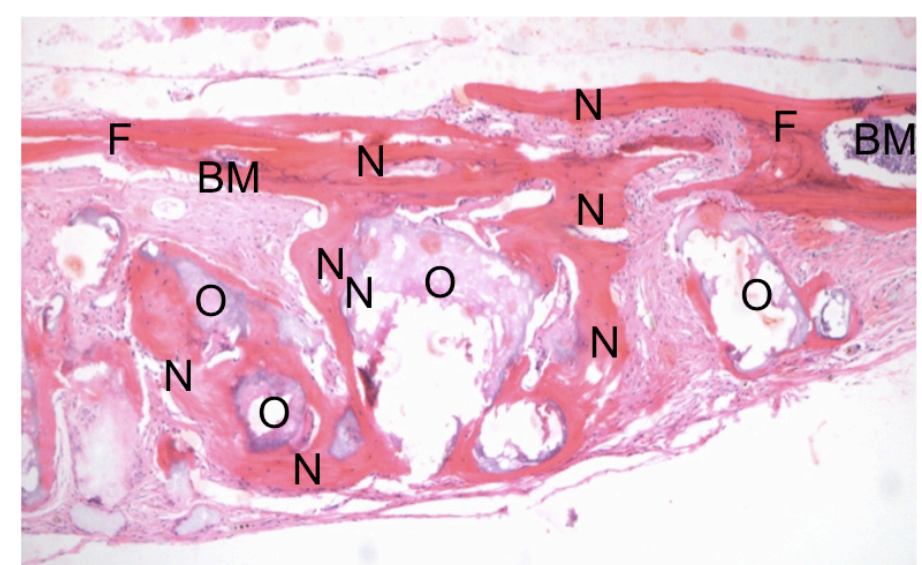

FIGURE 9 - Histological aspect of reconstruction with calcium phosphate. There is cortical fusion $(\mathbf{F})$, new bone formation $(\mathbf{N})$, presence of bone marrow $(\mathbf{B M})$ and old and unabsorbed matrix $(\mathbf{O})(\mathrm{x} 100)$.

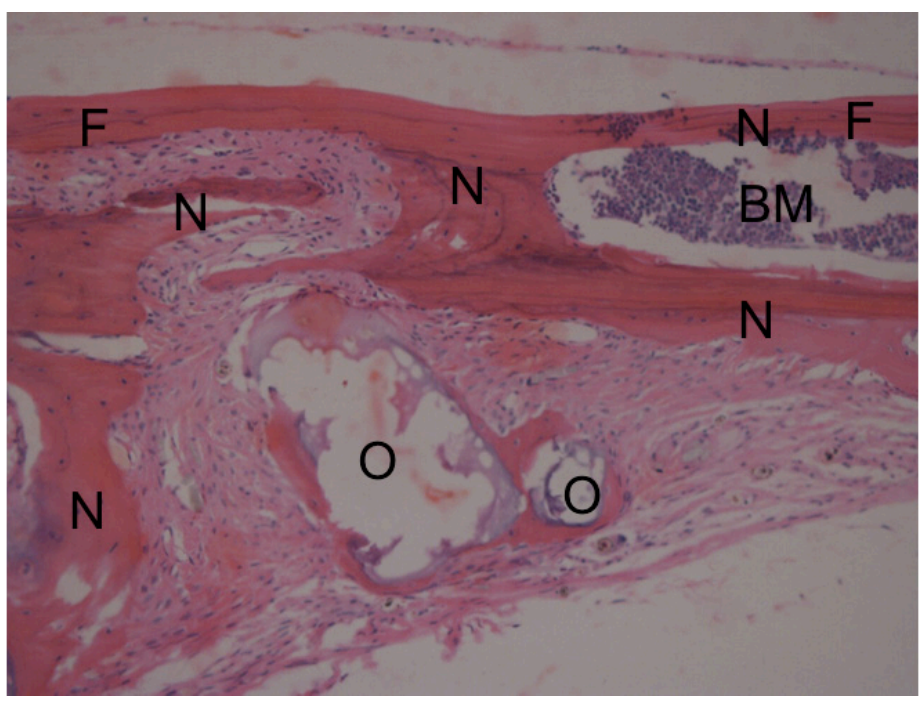

FIGURE 10 - Histological aspect of reconstruction with calcium phosphate. There is cortical fusion $(\mathbf{F})$, new bone formation $(\mathbf{N})$, and presence of bone marrow (BM) and old and unabsorbed matrix (O) (x200).

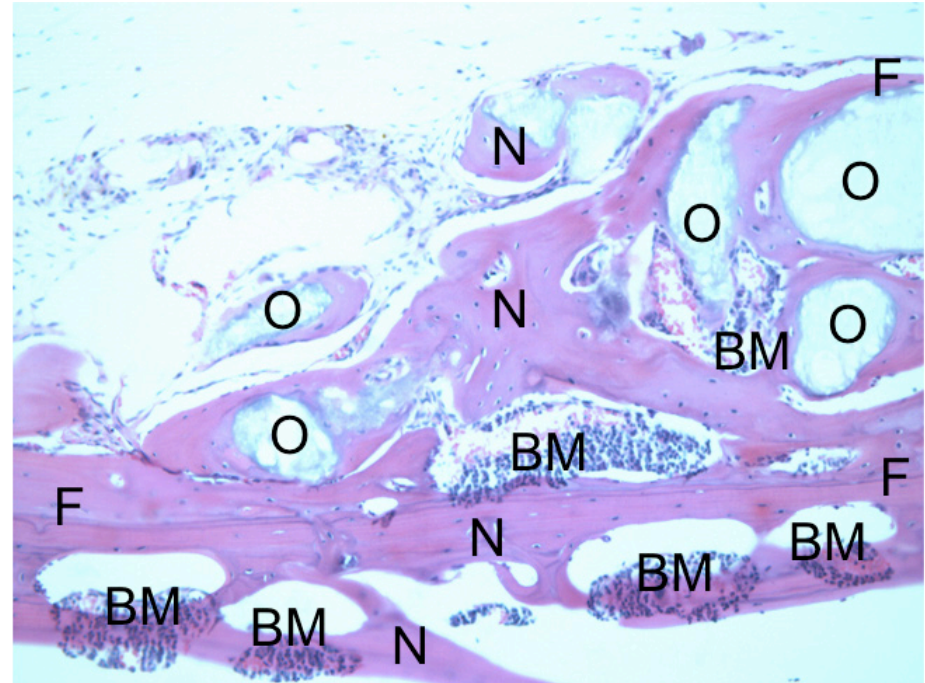

FIGURE 11 - Histological aspect of calcium phosphate and bone morphogenetic protein-2. There is cortical fusion $(\mathbf{F})$, new bone formation $(\mathbf{N})$, and presence of bone marrow (BM) and old and unabsorbed matrix (O) $(\mathrm{x} 200)$.

TABLE 2 - Histological analysis.

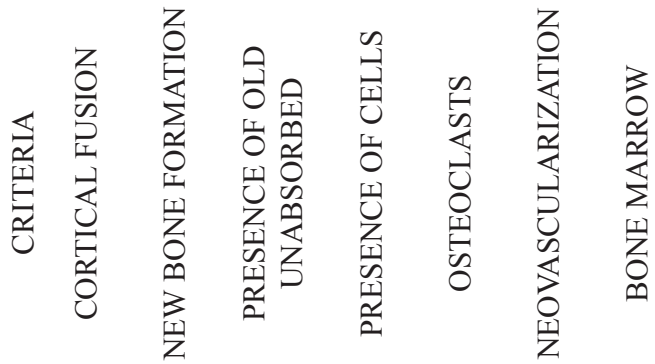

SCORING $[0 ; 2] \quad[0 ; 3] \quad[-3 ; 0] \quad[0 ; 3] \quad[0 ; 3] \quad[0 ; 3] \quad[0 ; 1] \quad[-3 ; 15]$ GROUP

\begin{tabular}{|c|c|c|c|c|c|c|c|c|}
\hline \multicolumn{9}{|l|}{$\overline{\mathrm{BAG}}$} \\
\hline average & 2.0 & 2.8 & -0.4 & 2.8 & 0.2 & 2.4 & 1.0 & 10.8 \\
\hline median & 2.0 & 3.0 & 0.0 & 3.0 & 0.0 & 3.0 & 1.0 & 12.0 \\
\hline $\mathrm{sd}$ & 0.0 & 0.4 & 0.5 & 0.4 & 0.4 & 0.9 & 0.0 & 1.8 \\
\hline \multicolumn{9}{|l|}{ ALG } \\
\hline average & 0.2 & 0.8 & -3.0 & 3.0 & 0.0 & 2.3 & 0.0 & 3.3 \\
\hline median & 0.0 & 1.0 & -3.0 & 3.0 & 0.0 & 2.0 & 0.0 & 3.0 \\
\hline $\mathrm{sd}$ & 0.4 & 0.8 & 0.0 & 0.0 & 0.0 & 0.5 & 0.0 & 1.0 \\
\hline \multicolumn{9}{|l|}{ TCP } \\
\hline average & 2.0 & 2.3 & -3.0 & 3.0 & 0.3 & 3.0 & 0.6 & 8.1 \\
\hline median & 2.0 & 2.0 & -3.0 & 3.0 & 0.0 & 3.0 & 1.0 & 9.0 \\
\hline $\mathrm{sd}$ & 0.0 & 0.5 & 0.0 & 0.0 & 0.5 & 0.0 & 0.5 & 1.1 \\
\hline \multicolumn{9}{|l|}{ MDM } \\
\hline average & 1.3 & 1.3 & -2.7 & 3.0 & 0.3 & 3.0 & 0.3 & 6.7 \\
\hline median & 1.0 & 1.0 & -3.0 & 3.0 & 0.0 & 3.0 & 0.0 & 7.0 \\
\hline $\mathrm{sd}$ & 0.6 & 0.6 & 0.6 & 0.0 & 0.6 & 0.0 & 0.6 & 1.5 \\
\hline \multicolumn{9}{|l|}{$\mathrm{BA}$} \\
\hline average & 0.7 & 1.3 & -3.0 & 3.0 & 0.0 & 3.0 & 0.2 & 5.2 \\
\hline median & 0.5 & 1.5 & -3.0 & 3.0 & 0.0 & 3.0 & 0.0 & 5.0 \\
\hline $\mathrm{sd}$ & 0.8 & 0.8 & 0.0 & 0.0 & 0.0 & 0.0 & 0.4 & 1.3 \\
\hline \multicolumn{9}{|l|}{ BT } \\
\hline average & 1.6 & 3.0 & -3.0 & 3.0 & 0.0 & 1.0 & 0.8 & 6.4 \\
\hline median & 2.0 & 3.0 & -3.0 & 3.0 & 0.0 & 1.0 & 1.0 & 7.0 \\
\hline $\mathrm{sd}$ & 0.9 & 0.0 & 0.0 & 0.0 & 0.0 & 1.2 & 0.4 & 2.2 \\
\hline \multicolumn{9}{|l|}{$\mathrm{BM}$} \\
\hline average & 1.2 & 1.8 & -3.0 & 3.0 & 0.0 & 3.0 & 0.5 & 6.5 \\
\hline median & 1.0 & 1.5 & -3.0 & 3.0 & 0.0 & 3.0 & 0.5 & 5.5 \\
\hline $\mathrm{sd}$ & 0.8 & 1.0 & 0.0 & 0.0 & 0.0 & 0.0 & 0.5 & 2.0 \\
\hline
\end{tabular}

Abbreviations: ALG: alginate; BA: BMP+ALG; BAG: bone autograft; $\mathrm{BM}$ : BMP+MDM; BMP: bone morphogenetic protein; BT: BMP+TCP; MDM: acellular dermal matrix; sd: standard deviation; TCP: calcium phosphate. 
After summing the histological criteria, there has been difference among groups $(p=0.000275)$. BAG has obtained the best result, 10.8 points, and ALG the worst, 3.3 points. In more detail, both groups with ALG (ALG and BA) have presented the worst punctuation. What draws attention is the fact that BT group (6.4 points) has stand back its own control group, TCP (8.1 points), after final sum of criteria. This has been clarified after separated analysis of criteria.

Cortical fusion criterion has showed statistical difference among groups $(\mathrm{p}=0.000846)$. This time, TCP group has reached the same punctuation as BAG (2 points), while BT group, has come soon after them (1.6 points), a non-significant difference $(\mathrm{p}=0.301)$. The groups ALG and BA have had the worst scoring (0.2 and 0.7 points respectively). MDM groups (MDM alone and BM: 1.3 and 1.2 points respectively) have remained in an intermediate position, demonstrating advantage in using such matrix, when compared to ALG. In this case, bone matrices have been superior to others, independently of BMP association.

The criterion new bone formation (or new bone trabeculae formation) has also demonstrated statistical difference among groups $(\mathrm{p}=0.00835$ ). The groups containing bone matrices (BT, $\mathrm{BAG}$, and TCP) have got the best scores, with BT in first place ( 3 points). BT group has equated BAG $(\mathrm{p}=0.317)$. There has been significance between BT and TCP (3.0 vs. 2.3 points, $\mathrm{p}=0.018$ ), privileging BMP association. After that, BMP groups, combining with non-bone matrices - BM and BA - have remained in an intermediate situation (1.8 and 1.3 points respectively), together with MDM group (1.3 points). ALG has stand in the last position with 0.8 points.

The criterion neovascularization has also presented significant differences among groups. The groups BM, BA, TCP, and MDM have obtained the same maximal score, 3 points. The intermediate positions have been got by AEN and ALG (2.4 and 2.3 points respectively), and last position has been occupied with BT, with 1 point.

The criterion bone marrow formation has also presented significant difference among groups $(\mathrm{p}=0.008317)$. BAG group has led the punctuation with 1 point (bone marrow formation in all the cases), followed by BT ( 0.8 points $)$ and TCP ( 0.6 points $)$ $(\mathrm{p}=0.241)$. As from BM (0.5 points), differences have become significant, when compared to AEN ( $\mathrm{p}=0.004689)$. The weaker groups have been BM (0.5 points), MDM (0.3 points), BA (0.2 points, and finally ALG, which presented no case of marrow formation.

In all groups, cellular concentration and colonization was intense in reconstructed area. There has been no difference among groups $(\mathrm{p}=0.359)$. Yet, there has been no difference as for the presence of osteoclasts in such area $(p=0.315)$.

At last, the criterion presence of unabsorbed matrix has been led by BAG. In this case, BAG has got the best scoring ( -0.4 points), which was significant ( $\mathrm{p}=0.00000961$ ).

\section{Discussion}

Bone regeneration has occurred in all of the studied groups, as evaluated by a histological scale. In the opening of reconstructed area, all of the failures have been fulfilled by some material, either fibrosis or bone.

It has draw attention of pathologists for the fact that BMP-2 groups have showed mature bone. Besides, inflammatory activity had been decreased. It denotes the ability of such molecule to accelerate bone regeneration. This diagnosis has been objective by the time of histological evaluation, but has not been measured, once it did not belong to the initial design of this study. Ideally, a future research, comparing bone changings weekly, could demonstrate BMP-2 properties in detail. Bone healing acceleration has already been evidenced in a previous study of ours ${ }^{25}$, in which an association between freeze-dried bone and mesenchymal stem cells has been compared to the matrix alone. In the group with cells, there has been a decrease in inflammatory phase duration. So, it would be possible to hypothesize than either stem cells or BMP-2 are healing accelerators, but such theory needs further research.

Fusion of new-formed trabeculae, at least at one side of the healing border, has occurred in groups BAG, TCP, and those with BMP-2. Fusion represents the property of osteointegration in a graft and this has been demonstrated in these groups ${ }^{3}$. Such findings represent promising alternatives, especially BT combination. A recent review about BMP-2 has argued that there are no orthopaedic studies demonstrating that BMP-2 alone overcomes BAG containing cancellous bone ${ }^{39}$.

BMP-2 and MDM have significantly stimulated neovascularization in bone failure. During the evaluation of this criterion, groups BM and BA have been upgraded, what can mean an increase in regenerative activity, but not necessarily a bone healing. BT group was the least scored, but bone formation was advanced, what may represent a faster bone regeneration and maturation. Nevertheless, our study design was not made to such evaluation.

Other groups, containing either BMP-2 or MDM, have overcome BAG group in the neovascularization criterion. This should be studied in other associations, especially with bone-like 
matrices. Perhaps, combining TCP, BMP-2, and MDM could produce a greater regeneration than such components alone.

The association between TCP and BMP-2 has conferred a satisfactory punctuation in histological analysis, keeping this group (BT) among the four better in scale final sum and also in new bone formation score. BT group has presented the lowest neovascularization score. However, the pathologists' analysis has evidenced that bone was in a later stage of regeneration, with a more mature bone. This could justify such findings. Jang et $a l^{41}$ have recently published a study in which reconstruction significantly improves by combining BMP-2, TCP, and hydroxyapatite (in a proportion $80 / 20$ of TCP/hydroxyapatite), when compared to their control groups. BMP-2 concentrations were higher than ours, ranging from .025 to $.2 \mathrm{mg} / \mathrm{ml}$. However, the authors have not seen statistical differences in such concentration effects.

The capacity of TCP groups - either combined or not to BMP-2 - is notorious in producing bone marrow in regenerative area (Figures 9 through 11). Yet, groups that contained MDM (either combined or not to BMP-2) were able to generate bone marrow after five weeks, despite the fact of been devoid of a bone matrix. In fact, BM group is an innovative association showed in this study, and its results are promising. MDM offer a structure that allows for both cell migration and neovascularization ${ }^{42,43}$.

TCP interaction with progenitor cells seems positive in some publications. TCP has a favourable tridimensional architecture, as well as the diameter of its pores. It is commercially available as blocks or granules. There are several papers combining TCP to GF, with positive and negative results ${ }^{40,44}$. Afifi et $a l .{ }^{45}$ have demonstrated that TCP alone has a non-negligible tax of complications in cranioplasties, especially when inserted in previously irradiated areas, or for those in contact with paranasal sinuses. However, it is an intensively studied biomaterial with many possibilities of therapeutic indications. Recently, Inzana et $a l .{ }^{46}$ made an experimental 9 -week study, in which they have showed bone healing optimization by introducing TCP scaffolds, manufactured in 3-D printers and combined to type-1 collagen.

Tridimensional architecture and porosity of a bone matrix are considered fundamental characteristics for its regenerative ability ${ }^{1,32,47}$. It may be seen in BAG and TCP groups, which have maintained a high score. Nevertheless, BMP-2 has secured bone formation and neovascularization, even when combined to scaffolds without bone features, as MDM and ALG. This finding denotes the great regenerative capability of BMP-2, as well as the possibility of associating it with malleable scaffolds for irregular failures. This way, we could obtain a versatile tool for reconstruction.
The introduction of regenerative cells in bone reconstruction is still a paradigm, but it may be discussed ${ }^{48}$. Our outcomes demonstrate that all the techniques have been able to conduct cells and tissue into receptor area (osteoconduction). However, there has been significant bone formation in groups BT and TCP, despite no regenerative cells were inserted. These group findings are probably comparable to those studies that employed cell cultures ${ }^{25}$. Such concern should be the base for future researches.

MDM have been increasingly used in reconstructive surgery. They may be employed, e.g., for covering joint areas with scar retractions, to increase facial aesthetics after burns, and to cover exposed tendons. In total-thick skin wounds, dermal reconstruction is fundamental for good aesthetical and functional outcomes. Dermal matrix or bone substitutes are manufactured with components of extracellular matrix: collagen and glycosaminoglycanes or hyaluronic acid ${ }^{43}$. Some matrices may receive a skin graft over it at the same time of implantation, other do not. It depends on their porosity and thickness. Thin matrices allow for transit of blood and nutrients into the graft, while the thick ones need vascular invasion before been ready to become a graft receptor layer. Combining MDM and bone matrices works better than the first alone ${ }^{32}$. Meantime, its use in bone failures is not well studied. Furthermore, MDM are susceptible to fast degradation in presence of bacterial of fungal contamination ${ }^{42,49}$. Its usage alone must be made only in low contaminated areas, but it is unknown if association to either GF or cell cultures increases resistance to contamination of even infection.

Incidence of infection in reconstruction areas was higher with MDM alone. This find represents the weakness of this material when not associated with other substances or in inadequate conditions. On the other hand, its association with BMP-2 (BM group) has reduced infection rate from $57 \%$ (4/7 cases) to zero, a new and innovative finding. It's likely that neovascularization promoted by BMP-2 may improve infection resistance, when comparing to MDM isolated. The review of Aspenberg ${ }^{39}$ mentions clinical trials where there has been less osteosynthesis in patients who have undergone BMP-2 treatment, corroborating to this data.

Besides, one of the greatest outcomes of this study was significant bone regeneration with BMP-2 and MDM association. This find has not often been found in medical literature, and may represent a great opportunity for either new experimental or clinical projects. As we have said before, combining BMP-2, TCP, and a covering of MDM may create "supergrafts".

BAG had the best result in the criterion presence of matrix. Meantime, such criteria may be criticized because we employed 
very different matrices and carriers. Still, BMP-2 concentration may have been relatively low, not accelerating healing to point of promoting a great resorption in some groups ${ }^{41}$.

Histological scale used in this study has been divided in order to increase precision. Although sum of criteria has kept BAG as the best scored group, separated analysis has showed several positive aspects in other groups.

The outcomes found and doubts aroused in this study take us to the following perspectives for new projects:

- BMP in different concentrations.

- MDM combined to tridimensional bone matrices.

- Cells in diverse stages of differentiation.

- Other associations among matrices, molecules, and cells.

- Associations between TE and gene therapy.

- Clinical trials in TE.

- Cost-benefit studies.

- BMP safety in oncological patients.

- Bioprinters in bone TE.

\section{Conclusions}

BMP-2 usage has improved parietal bone regeneration of cranial vault reconstructions in mice, according to histological evaluation, when combined with calcium phosphate, acellular dermal matrix or calcium alginate. Results were better with association than with these materials alone. Also, scores have been similar to BAG in some histological criteria, although bone autograft still remains the gold standard treatment.

\section{References}

1. Monaco E, Bionaz M, Hollister SJ, Wheeler MB. Strategies for regeneration of the bone using porcine adult adipose-derived mesenchymal stem cells. Theriogenology. 2011 May;75(8):138199. doi: 10.1016/j.theriogenology.2010.11.020.

2. Miyake H, Ohta T, Tanaka H. A new technique for cranioplasty with L-shaped titanium plates and combined hydroxyapatite and tricalcium phosphate (Ceratite). Neurosurgery. 2000 Feb;46(2):4148. PMID: 10690731.

3. Oryan A, Alidadi S, Moshiri A, Maffulli N. Bone regenerative medicine: classic options, novel strategies, and future directions. J Orthop Surg Res. 2014 Mar;9(18):1749-99. doi: 10.1186/1749799X-9-18.

4. Arias-Gallo J, Chamorro-Pons M, Avedaño C, Giménez-Gallego $\mathrm{G}$. Influence of acidic fibroblast growth factor on bone regeneration in experimental cranial defects using Spongostan and Bio-Oss as protein carriers. J Craniofac Surg. 2013 Sep;24(5):1507-14. doi: 10.1097/SCS.0b013e31828f2469.

5. Issack PS, DiCesare PE. Recent advances toward the clinical application of bone morphogenetic proteins in bone and cartilage repair. Am J Orthop. 2003 Sep;32(9):429-36. PMID: 14560824.

6. LucarelliE, DonatiD, CenacchiA, Fornasari PM. Bone reconstruction of large defects using bone marrow derived autologous stem cells. Transfus Apher Sci. 2004 Apr;30(2):169-74. PMID: 15062758.

7. Brodie JC, Goldie E, Connel G, Merry J, Grant MH. Osteoblast interactions with calcium phosphate ceramics modified by coating with type I collagen. J Biomed Mater Res. 2005 Jun;73(4):409-21. PMID 15892144.

8. Thesleff $T$, Lehtimäki $K$, Niskakangas $T$, Mannerström B, Miettinen S, Suuronen R, Öhman J. Cranioplasty with adiposederived stem cells and biomaterial: a novel method for cranial reconstruction. Neurosurgery 2011 Jun;68(6):1535-40. doi: 10.1227/ NEU.0b013e31820ee24e.

9. Chiarello E, Cadossi M, Tedesco G, Capra P, Calamelli C, Shehu A, Giannini S. Autograft, allograft and bone substitutes in reconstructive orthopedic surgery. Aging Clin Exp Res. 2013 Oct;25(Suppl.1):S101-3. doi: 10.1007/s40520-013-0088-8.

10. Andersen JR, Detlie T, Griffiths HJ. The radiology of bone allografts. Radiol Clin North Am. 1995 Mar;33(2):391-400. PMID: 7871175.

11. Perry CR. Bone repair techniques, bone graft and bone graft substitutes. Clin Orthop Relat Res. 1999 Mar; 360:71-86. PMID: 10101312.

12. Volpon JB, Costa RMP. Ensaio mecânico e uso clínico do enxerto homógeno processado. Rev Bras Ortop. 2000;35(6):219-24.

13. Rocque BG, Amancherla K, Lew SM, LAM S. Outcomes of cranioplasty following decompressive craniectomy in the pediatric population. J Neurosurg Pediatr. 2013 Aug;12(2):120-5. doi: 10.3171/2013.4.PEDS12605.

14. Mackenzie DJ, Sipe R, Buck D, Burgess W, Hollinger J. Recombinant human acidic fibroblast growth factor and fibrin carrier regenerates bone. Plast Reconstr Surg. 2001 Apr;107(4):9896. PMID: 11252093.

15. Oliveira ACP, Collares MVM, Galia CR, Edelweiss MI, Pinto RDA, Knebel L. Comparação entre enxerto ósseo autólogo, homólogo congelado e homólogo liofilizado em modelo experimental de cranioplastia. Rev Bras Cir Craniomaxilofac. 2007;10(4):140-6.

16. Portinho CP, Collares MVM, Silva FH, Nardi NB, Pinto RDA, Siqueira E, Morellato G, Sumino K. Reconstrução de calota craniana com células-tronco mesenquimais indiferenciadas: estudo experimental. Rev Bras Cir Plast. 2006;21(3):161-5.

17. Orsi VV, Collares MVM, Nardi NB, Pinto RDA, Meirelles LS, Meurer L, Pilla C, Portinho CP, Riboldi M, Auer TB. Osso liofilizado bovino não-desmineralizado com células-tronco mesenquimais para engenharia tecidual: estudo experimental em sítio heterotópico. Rev Bras Cir Craniomaxilofac. 2007;10(4):133-9.

18. Moshaverinia A, Ansari S, Chen, Xu X, Akiyama K, Snead ML, Zadeh HH, Shi S. Co-encapsulation of anti-BMP2 monoclonal antibody and mesenchymal stem cells in alginate microspheres for bone tissue engineering. Biomaterials. 2013 Sep:34(28):6572-9. doi: 10.1016/j.biomaterials.2013.05.048.

19. Poldervaart MT, Wang H, van der Stok J, Weinans H, Leeuwenburgh SC, Oner FC, Dhert WJ, Alblas J. Sustained release of BMP-2 in bioprinted alginate for osteogenicity in mice and rats. PLoS One. 2013 Aug;8(8):e72610. doi: 10.1371/journal.pone.0072610

20. Xu XL, Lou J, Tang T, Ng KW, Zhang J, Yu C, Dai K. Evaluation of different scaffolds for BMP-2 genetic orthopedic tissue engineering. J Biomed Mater Res B Appl Biomater. 2005 Nov;75(2):289-303. PMID: 16025445.

21. Galateanu B, Dimonie D, Vasile, Nae S, Cimpean A, Costache M. Layer-shaped alginate hydrogels enhance the biological performance of human adipose-derived stem cells. BMC Biotechnol. 2012 Jun:12(35):1-14. doi: 10.1186/1472-6750-12-35.

22. Smidsrod O, Skjak-Braek G. Alginate as immobilization matrix for cells. Trends Biotechnol. 1990 Mar;8(3):71-8. PMID: 1366500.

23. Simmons CA, Alsberg E, Hsiong S, Kim WJ, Mooney DJ. Dual 
growth factor delivery and controlled scaffold degradation enhance in vivo bone formation by transplanted bone marrow stromal cells. Bone. 2004 Aug;35(2):562-9. PMID: 15268909.

24. Pound JC, Green DW, Chaudhuri JB, Mann S, Roach HI, Oreffo RO. Strategies to promote chondrogenesis and osteogenesis from human bone marrow cells and articular chondrocytes encapsulated in polysaccharide templates. Tissue Eng. 2006 Oct;12(10):2789-99. PMID: 17518648.

25. Portinho CP, Riboldi M, Pilla C, Collares MVM, Silva FH, Meirelles LS, Nardi NB, Pinto RDA. Fosfatase alcalina em enxertos ósseos contendo células-tronco. Rev Bras Cir Craniomaxilofac. 2007;10(3):97-100.

26. Malafaya PB, Silva GA, Reis RL. Natural-origin polymers as carriers and scaffolds for biomolecules and cell delivery in tissue engineering applications. Adv Drug Deliv Rev. 2007 May;59(45):207-33. PMID: 17482309

27. Padoin AV, Braga-Silva J, Martins P, Rezende K, Rezende AR, Grecchi B, Gehlen D, Machado DC. Sources of processed lipoaspirate cells: influence of donor site on cell concentration. Plast Reconstr Surg. 2008 Aug;122(2):614-8. doi: 10.1097/ PRS.0b013e31817d5476.

28. Slaughter BV, Khurshid SS, Fisher OZ, Khademhosseini A, Peppas NA. Hydrogels in regenerative medicine. Adv Mater. 2009 Sep;21(32-33):3307-29. doi: 10.1002/adma.200802106.

29. Carrodeguas RG, De Aza S. Alfa-tricalcium phosphate: synthesis, properties and biomedical applications. Acta Biomater. 2011 Oct;7(10):3536-46. doi: 10.1016/j.actbio.2011.06.019.

30. Nae S, Bordeianu I, Stancioiu AT, Antohi N. Human adipose-derived stem cells: definition, isolation, tissue-engineering applications. Rom J Morphol Embryol. 2013;54(4):919-24. PMID: 24398986.

31. Sommar P, Junker JP, Strandenes E, Ness C, Hansson T, Johnson H, Kratz G. Osteogenically-induced human dermal fibroblasts as a tool to regenerate bone. J Plast Surg Hand Surg. 2013 Feb;47(1):8-13. doi: 10.3109/2000656X.2012.731411.

32. Ge S, Zhao N, Wang L, Liu H, Yang P. Effects of hydroxyapatite nanostructure on channel surface of porcine acellular dermal matrix scaffold on cell viability and osteogenic differentiation of human periodontal ligament stem cells. Int J Nanomedicine. 2013 May;8:1887-95. doi: 10.2147/IJN.S44695.

33. Ito A, Mase A, Tazikawa Y, Shinkai M, Honda H, Hata K, Ueda M, Kobayashi T. Transglutaminase-mediated gelatin matrices incorporating cell adhesion factors as a biomaterial for tissue engineering. J Biosci Bioeng. 2003;95(2):196-9. PMID: 16233392.

34. Dudas JR, Marra KG, Cooper GM, Penascino VM, Mooney MP, Jiang S, Rubin JP, Losee JE. The osteogenic potential of adiposederived stem cells for the repair of rabbit calvarial defects. Ann Plast Surg. 2006 May;56(5):543-8. PMID: 16641633.

35. Smith DM, Cooper GM, Afifi AM, Mooney MP, Cray J, Rubin JP, Marra KG, Losee JE. Regenerative surgery in cranioplasty revisited: the role of adipose-derived stem cells and BMP-2. Plast Reconstr Surg. 2011 Nov;128(5):1053-60. doi: 10.1097/ PRS.0b013e31822b65e4

36. Lópiz-Morales Y, Abarrategi A, Ramos V, Moreno-Vicente C, López-Durán L, López-Lacomba JL, Marco F. In vivo comparison of the effects of rhBMP-2 and rhBMP-4 in osteochondral tissue regeneration. Eur Cell Mater. 2010 Dec;20:367-78. PMID: 21154243.

37. Jain AP, Pundir S, Sharma A. Bone morphogenetic proteins: the anomalous molecules. J Indian Soc Periodontol. 2013 Sep;17(5):5836. PMID: 24174749.

38. Owens P, Polikowsky H, Pickup MW, Gorska AE, Jovanovic B, Shaw AK, Novitskiy SV, Hong CC, Moses HL. Bone morphogenetic protein stimulate mammary fibroblasts to promote mammary carcinoma cell invasion. Plos One. 2013Jun;8(6):e67533. doi: 10.1371/journal.pone.0067533.

39. Aspenberg P. Special review: accelerating fracture repair in humans: a reading of old experiments and recent clinical trial. Bonekey Rep. 2013 Jan;2:244. PMID: 24404375.

40. Özdemir B, Kurtis B, Tüter G, Sengüven B, Tokman B, PinarÖzdemir S, Demirel I, Özcan G. Double-application of platelet-rich plasma on bone healing in rabbits. Med Oral Patol Oral Cir Bucal. 2012 Jan;17(1):e171-7. PMID: 22157673.

41. Jang JW, Yun JH, Lee KI, Jang JW, Jung UW, Kim CS, Choi SH, Cho KS. Osteoinductive activity of biphasic calcium phosphate with different rhBMP-2 doses in rats. Oral Surg Oral Med Oral Pathol Oral Radiol. 2012 Apr;113(4):480-7. doi: 10.1016/j.tripleo.2011.04.013.

42. Pereima MJ, Capella MR, Goldberg P, Quaresma E, Araújo EJ, Souza JA, Azevedo M, Colombeli EM, Feijó RS, Souza VA Jr, Perdomo HAR. Uso de matrizes dérmicas no tratamento de queimaduras em crianças: análise de 11 casos. Arq Catarin Med. 2012;34(1):38-46.

43. Philandrioanos C, Andrac-Meyer L, Mordon S, Feuerstein JM, Sabatier F, Veran J, Magalon G, Casanova D. Comparison of five dermal substitutes in full-thickness skin wound healing in a porcine model. Burns. 2012 Sep;38(6):820-9. doi: 10.1016/j. burns.2012.02.008.

44. Özdemir B, Okte E. Treatment of intrabony defects with betatricalcium phosphate alone and in combination with plateletrich plasma. J Biomed Mater Res B Appl Biomater. 2012 May;100(4):976-83. doi: 10.1002/jbm.b.32660.

45. Afifi AM, Gordon CR, Pryor LS, Sweeney W, Papay FA, Zins JE. Calcium phosphate cements in skull reconstruction: a meta-analysis. Plast Reconstr Surg. 2010 Oct;126(4):1300-9. doi: 10.1097/ PRS.0b013e3181 ead057.

46. Inzana JA, Olvera D, Fuller SM, Kelly JP, Graeve OA, Schwarz EM, Kates SL, Awad HA. 3D printing of composite calcium phosphate and collagen scaffolds for bone regeneration. Biomaterials. 2014 Apr;35(13):4026-34. doi: 10.1016/j.biomaterials.2014.01.064.

47. Kuboki Y, Jin Q, Kikuchi M, Mamood J, Takita H. Geometry of artificial ECM: sizes of pores controlling phenotype expression in BMP-induced osteogenesis and chondrogenesis. Connect Tissue Res. 2002;43(2-3):529-34. PMID: 12489210.

48. Schantz JT, Brandwood A, Hutmacher DW, Khor HL, Bittner $\mathrm{K}$. Osteogenic differentiation of mesenchymal progenitor cells in computer designed fibrin-polymeric-ceramic scaffolds manufactured by fused deposition modeling. J Mater Sci Mater Med. 2005 Sep;16(9):807-19. PMID: 16167109.

49. Simã o TS, Pitol DN, Máximo FR, Mattar CA, Faiwichow L. Uso de matriz dérmica bovina no tratamento de contraturas pós-queimaduras de membros superiores. Rev Bras Queimad. 2012;11(3):142-5.

\section{Acknowledgements}

To the members of Animal Experimental Division, Research Center, Porto Alegre Clinics Hospital.

\section{Correspondence:}

Ciro Paz Portinho

Hospital de Clínicas de Porto Alegre

Serviço de Cirurgia Plástica

Rua Ramiro Barcelos, 2350/600E

90035-003 Porto Alegre - RS Brasil

Tel.: (55 51)9998-3979 / 3359-8232

cportinho@hotmail.com 
Portinho CP et al.

Received: May 19, 2014

Review: July 18, 2014

Accepted: Aug 22, 2014

Conflict of interest: none

Financial source: Incentive Fund for Research and Events (FIPE)

${ }^{1}$ Research performed at Animal Experimental Division, Research Center, Plastic Surgery Department; Pathology Department, Porto Alegre Clinics Hospital, and Laboratory of Biomateriais and Advanced Ceramics, Material Engineering Department, Federal University of Rio Grande do Sul (UFRGS), Brazil. Part of PhD degree thesis, Postgraduate Program in Surgical Sciences, Medical School, UFRGS. Tutor: Prof. Dr. Marcus Vinícius Martins Collares. 